\title{
Laboratory Rearing of the Hairy Chinch Bug ${ }^{1,2,3}$
}

\author{
P. B. BAKER, ${ }^{4}$ R. H. RATCLIFFE AND A. L. STEINHAUER ${ }^{5}$ \\ Field Crops Laboratory, Agricultural Research, SEA, USDA, Beltsville, Maryland 20705
}

ABSTRACT

Environ. Entomol. 10: 226-229 (1981)

Laboratory procedures were developed for rearing the hairy chinch bug Blissus leucopterus hirtus Montandon, on corn sections in $236.6 \mathrm{ml}$ cardboard cartons. There was significantly higher survival of nymphs and adults when eggs were surface sterilized in $2 \%$ sodium hypochlorite solution as compared to those treated with a $1 \%$ solution or untreated eggs. Adult survival was significantly higher $(\mathrm{P}<0.05)$ when chinch bugs were reared on corn sections treated with $2 \%$ sodium hypochlorite than when either treated with $2 \%$ thiram or untreated. Developmental times for nymphal instars were determined as follows: 1st $12.3 \pm 6.0 ; 2$ nd $5.4 \pm 2.7$; 3rd $5.2 \pm 1.7 ; 4$ th $4.9 \pm 1.3 ; 5$ th $7.1 \pm 0.9$; total $35.5 \pm 7.4$ days. The preoviposition period was determined to be $10.8 \pm 4.4$ days with nearly $80 \%$ of the females tested ovipositing within 24 days.

The hairy chinch bug, Blissus leucopterus hirtus Montandon is one of the major insect pests attacking turfgrasses in the Northeastern United States. Its increased importance in recent years is due, in part, to development of insecticide iesistance (Streu and Cruz 1972). It feeds on most of the cool season turfgrasses, including red fescue, Festuca rubra L., perennial ryegrass, Lolium perenne L., bentgrass, Agrostis species, and Kentucky bluegrass, Poa pretensis L. Although insecticides still provide the major means of control, problems associated with their continual use have emphasized the need for development of other control methods, including resistant varieties. The studies reported in this paper were conducted in conjunction with a program to select for plant resistance to the hairy chinch bug at Beltsville, Maryland. Evaluation of plant germplasm in the laboratory on a continuous basis required a readily available supply of test insects in various developmental stages. It was impossible to meet these needs from natural populations since the hairy chinch bug generally is not present in large numbers in the field in the Beltsville area except for a limited period in August and September. Also, attempts to rear this insect on potted plants or excised leaves of several grasses in the laboratory were not successful in meeting the needs of the resistance program, although small numbers could be maintained by this means.

\section{Materials and Methods}

\section{Rearing Studies}

Parker and Randolph (1972) reported rearing the chinch bug, B. leucopterus leucopterus (Say), on com sections in 3.8 liter cardboard containers in the laboratory. We attempted to rear the hairy chinch bug using their method, but found that it was not adequate for rearing large numbers of individuals because of the high mortality of early instars. Mortality appeared to be as-

\footnotetext{
${ }^{1}$ Hemiptera: Lygaeidae.

Scientific Article No. A-2684. Contribution No. 5729 of the MD Agric. Exp. Sin. Received for publication Dec. 17, 1979.

${ }^{3}$ This paper reports the results of research only. Mention of a commercial product does not constitute recommendation or endorsement by the USDA or University of Maryland.

L Dept. of Entomology, University of Maryland, College Park, MD 20742. Senior author's present address: Dept. of Entomology, NYS Agric. Expt. Stn. Geneva, NY 14456

Department of Entomology, University of Maryland, College Park, MD.
}

sociated primarily with fungi growth on the corn sections and eggs which trapped young nymphs. To reduce the mold and thus increase survival in the early instars, we conducted 2 studies to investigate the influence of surface sterilization of eggs and corn on fungi and other possible organisms. Once adequate methods for rearing the insect were developed, we conducted a series of tests to determine the biology of the insect reared by this procedure.

The following general procedures were used in all rearing and biology studies. Field corn, grown in the greenhouse under a $16-18 \mathrm{~h}$ photoperiod of natural and artificial light was harvested when 4-6 weeks old and stems cut into $7.5 \mathrm{~cm}$ sections. One cut end was coated with paraffin to reduce moisture loss. Adults, used for egg sources were maintained in 1.9 liter cartons fed with corn sections and were supplied with 2 rolls of cheesecloth to serve as oviposition sites as described by Parker and Randolph (1972). Eggs were collected and placed on moist filter paper on a moistened sponge in a $9 \times$ $1.9 \mathrm{~cm}$ petri dish. The petri dish was then placed in the 1.9 liter carton with corn sections. After hatch, nymphs crawled from the moist filter paper to the corn sections. The corn sections and cartons were changed at least weekly until all nymphs had matured or died. Cartons were placed in clear plastic bags in an environmental chamber maintained at $26^{\circ} \mathrm{C}, 40-75 \% \mathrm{RH}$ and a $16-\mathrm{h}$ photoperiod.

\section{Egg Treatment}

Eggs were collected from 1st generation laboratoryreared adults and were treated with either 1 or $2 \%$ sodium hypochlorite $(\mathrm{NaOCl})$ solution or distilled water. Eggs were surface-sterilized (treatments 1 and 2) by immersing them for $20 \mathrm{~min}$ in the $\mathrm{NaOCl}$ solution and then in distilled water for $20 \mathrm{~min}$. Unsterilized eggs (treatment 3) were immersed only in distilled water for $20 \mathrm{~min}$. Following removal from the distilled water 30 eggs per treatment were transferred by brush to a $5.5 \times$ $1.2 \mathrm{~cm}$ petri dish with a moist filter paper on a moist sponge. Petri dishes were placed into cartons with 2 corn sections, which provided food for hatching nymphs. Before corn sections were placed in cartons, they were also surface-sterilized in a $2 \% \mathrm{NaOCl}$ solution for 20 $\mathrm{min}$, rinsed in distilled water for $20 \mathrm{~min}$ and allowed to 
air dry on paper towels. A $10 \mathrm{~cm}^{2}$ piece of paper towel was forced over the rim of the carton by the carton top to form a tight seal. Each treatment was replicated 5 times on 3 dates. Observations were made on nymphal development every 3-5 days, and cartons and corn sections were changed weekly.

\section{Corn Treatment}

Eggs were surface-sterilized in $2 \% \mathrm{NaOCl}$, rinsed and transferred to petri dishes and placed in cartons with 2 corn sections as aforementioned. Prior to placement in cartons, com sections were divided into 3 groups and treated as follows: treatment (1) - immersed for $20 \mathrm{~min}$ in $2 \% \mathrm{NaOCl}$ solution, rinsed in distilled water for 20 min and air dried on paper towels; (2) - immersed for $20 \mathrm{~min}$ in a $2 \%$ thiram solution and air dried on paper towels; treatment (3) - no treatment. A water vial (6.8 $\times 1.8 \mathrm{~cm}$ ) with a cotton plug was added to each container to maintain high relative humidity. Nymphal development was checked every 3-5 days at which time corn sections and cartons were changed. Each treatment was replicated 5 times on 4 dates.

\section{Biology Studies}

Nymphal development.-Eggs were collected, surface-sterilized in $2 \% \mathrm{NaOCl}$ and handled as described in the general procedure until 5-7 days old. At that time, 75 red eggs (indicating embryo development) were transferred singly to moist filter paper disks $\left(0.6 \mathrm{~cm}^{2}\right)$ and placed in cartons. Prior to this, the bottom seam of each carton was sealed with melted wax and the upper $2 \mathrm{~cm}$ of the inside surface was coated with talcum powder. Two corn sections, surface-sterilized with $2 \%$ $\mathrm{NaOCl}$ were placed in the carton over a $3.2 \mathrm{~cm}^{2}$ section of paper towel. Cartons were then closed and stored as described in the general procedure. Nymphal development was observed daily and com sections were changed every 3-5 days.
Female longevity and oviposition.-Fourth and 5th instars were collected from the field and 1 st generation laboratory colonies and maintained in separate 1.9 liter cardboard cartons on corn sections until mature. Newly emerged females were removed daily and placed individually with a male and $2-3$ corn sections in $236.6 \mathrm{ml}$ cardboard cartons with a vented top. Cartons were held in a reach-in chamber as in previous studies. Eggs were collected every 2-3 days and corn sections changed weekly. Dead males were replaced. The total number of eggs/day/female was compared for laboratory and field collected adults. Total egg counts included viable and nonviable (collapsed) eggs.

Preoviposition period.-First generation laboratory reared 4 th and 5 th instars were pooled in 1.9 liter cardboard cartons on corn sections. Newly emerged adults were collected for each day and pooled in $236.6 \mathrm{ml}$ cartons on corn sections. After 3-5 days, individual females were confined with at least one male and placed with $2-4$ corn sections in $236.6 \mathrm{ml}$ cartons with a vented top. Cartons were checked for eggs daily and corn sections were changed weekly.

\section{Results and Discussion}

\section{Rearing Studies}

Test $I-E g g$ treatment.-There was no significant effect of treatment on egg hatch or survival of 1st and 2nd instars (Table 1). However, mortality through the 2nd stadium was high (ca. 70\%) for all treatments with over $55 \%$ occurring from loss or death of nymphs. Survival of 3 rd to 5 th instars and adults was highest from groups receiving the $2 \% \mathrm{NaOCl}$ treatment, however, we cannot explain why egg treatment should influence survival of older nymphs or adults. The modification that we made to Parker and Randolph's (1972) technique, such as smaller cartons, more frequent changing of corn sections, and maintaining higher $\mathrm{RH}$, improved

Table 1.-A partial life table of the hairy chinch bug reared on corn stem sections after eggs were treated with distilled water, 1 or $2 \%$ sodium hypochlorite.

\begin{tabular}{|c|c|c|c|c|}
\hline $\begin{array}{c}\% \\
\text { sodium } \\
\text { hypochlorite }\end{array}$ & $\begin{array}{c}\text { Age } \\
\text { interval } \\
(X)\end{array}$ & $\begin{array}{l}\text { Mean no. } \\
\text { alive at } \\
\text { start of } \\
\text { age interval }{ }^{2}\end{array}$ & $\begin{array}{l}\text { Mean no. } \\
\text { dying } \\
\text { during } \\
\text { age interval }\end{array}$ & $\begin{array}{c}\% \\
\text { mortality } \\
\text { during } \\
\text { age interval }\end{array}$ \\
\hline \multicolumn{5}{|c|}{ Egg } \\
\hline 2 & \multirow{7}{*}{$1-2 n d$ instar } & $30 a$ & 5.2 & 17.3 \\
\hline 1 & & $30 a$ & 4.7 & 15.5 \\
\hline 0 & & $30 a$ & 6.3 & 21.1 \\
\hline & & & & \\
\hline 2 & & $24.8 \mathrm{a}$ & 15.6 & 62.9 \\
\hline 1 & & $25.4 \mathrm{a}$ & 16.7 & 65.7 \\
\hline 0 & & $23.6 \mathrm{a}$ & 17.7 & 75.0 \\
\hline & \multirow[t]{4}{*}{ 3-5 instar } & & & \\
\hline 2 & & $9.2 \mathrm{a}$ & 2.3 & 25.0 \\
\hline 1 & & $8.7 \mathrm{~b}$ & 4.6 & 52.8 \\
\hline 0 & & $6.0 \mathrm{a}$ & 2.1 & 35.0 \\
\hline & \multirow[t]{4}{*}{ Adult } & & & \\
\hline 2 & & $6.8 \mathrm{a}$ & .1 & 1.1 \\
\hline 1 & & $4.0 \mathrm{~b}$ & .1 & 3.2 \\
\hline 0 & & $4.6 \mathrm{~b}$ & .2 & 3.4 \\
\hline
\end{tabular}

I 15 replications.

2 Means not followed by the same leter are significantly different $(\mathrm{P}<0.05)$ (Duncan's multiple range test). 
nymphal survival over that obtained in our initial attempts. However, it was still necessary to reduce the high mortality occurring to the early instars if this method was to be used successfully in rearing the lairy chinch bug.

Test 2-Corn treatment.-There was no significant effect of corn treatment on egg hatch, however nymphal survival through the 2nd stadium was significantly greater $(P<0.05)$ on untreated corn or corn treated with $2 \% \mathrm{NaOC} 1$ than on corn treated with $2 \%$ thiram (Table 2). There were no significant differences in survival of 3rd-5th instars among treatments and over $80 \%$ of the 3 rd instars matured to adults. However, the total number of insects reaching maturity was significantly greater on $2 \% \mathrm{NaOC} 1$ treated corn than on either untreated or thiram-treated corn.

A comparison of the 2 studies showed that increased production of adults in the corn treatment test resulted primarily from higher survival of 1 st and 2nd instars. Egg hatch and survival of 3rd-5th instars to adults was in most cases very similar (ca. $80 \%$ ) in both tests. It appears that improved survival in the latter test resulted primarily from more frequent changing of corn sections rather than from the influence of corn treatments per se, although survival was slightly higher on the $\mathrm{NaOCl}$ treated stems than untreated stems. A comparison of results of the 2 studies shows that there was approximately $20 \%$ increase in survival for 1st-2nd instars, a $10 \%$ increase in survival of 3 rd to 5 th instars, and a $50 \%$ increase in the production of adults when corn rather than eggs were surface-sterilized. This in tum resulted in an overall increase in adults obtained to $41 \%$ on $2 \% \mathrm{NaOC} 1-$ treated stems in the corn treatment compared to $22 \%$ in the egg treatment tests.

There was no significant effect of egg or corn treatment on sex ratio or \% of brachypterous or macropterous produced within each study. Under these conditions there was a slightly higher $\%$ of $\delta \delta$ produced $(53 \%)$ and more brachyterous of both sexes; $82 \%$ for $\delta \delta$ and
$64 \%$ for $q 9$. Leonard (1966) reported B. leucopterus hirtus as having an overall total of $63.7 \%$ brachypterous population. Luginbill (1922) and Chambliss (1895) reported a majority of the spring generation were longwing forms and summer generation were short-wing forms for B. leocopterus. Sweet (1964) in reporting on the biology and ecology of the Rhyparochrominae of New England (Lygaeidae) found a good correlation between the proportion of brachypterous forms and permanency of habitat. Leonard (1966) indicated a similar strong correlation was evident in some species of Blissus. Based on these reports, one would expect a higher $\%$ of brachypterous adults among the hairy chinch bug reared under the conditions of this study.

\section{Biology Studies}

Nymphal development. - The development time, in days, for the various instars was as follows: 1st$12.3 \pm 6.0 ; 2$ nd $-5.4 \pm 2.7 ; 3$ rd $-5.2 \pm 1.7 ; 4$ th $-4.9 \pm 1.3$; 5 th $-7.1 \pm 0.9$; total $35.5 \pm 7.4$ days. The development time for the first 3 instars was very similar to that reported by Luginbill (1922) for the chinch bug $B$. leucopterus reared on corn leaves in small shell vials. However, Luginbill (1922) reported a much longer development time of 14.7 and 24.6 days for the 4th and 5 th instars, respectively. This resulted in a total development time of 66.4 days to adult, which is almost twice that found for the hairy chinch bug in this study. Chambliss (1895) and Snelling et al. (1937) reported B. leucopterus developed in 4-6 weeks on small grains in the Midwest. In Maryland the hairy chinch bug develops in approximately 4-6 weeks in the summer. Therefore, the developmental time reported here appears to be within the range that might be expected on field plants. Luginbill (1922) also reported that the length of the immature stages was somewhat extended in his study because the nymphs were kept under unnatural conditions. This could also result from feeding on excised corn sections since, as tissues degenerate, certain nutrients may be-

Table 2.-A partial life table of the hairy chinch bug reared on corn stem sections which were treated with $2 \%$ sodium hypochlorite (NaOC1), thiram or untreated.'

\begin{tabular}{|c|c|c|c|c|}
\hline Treatment & $\begin{array}{l}\text { Age interval } \\
(\mathrm{X})\end{array}$ & $\begin{array}{l}\text { Mean no. alive at } \\
\text { start of age interval }{ }^{2}\end{array}$ & $\begin{array}{l}\text { Mean no. dying } \\
\text { during age interval }\end{array}$ & $\begin{array}{c}\% \\
\text { mortality } \\
\text { during } \\
\text { age interval }\end{array}$ \\
\hline \multicolumn{5}{|c|}{ Egg } \\
\hline $\mathrm{NaOCl}$ & & $30 \mathrm{a}$ & 5.0 & 16.6 \\
\hline Thiram & & $30 \mathrm{a}$ & 4.7 & 15.5 \\
\hline Untreated & & $30 a$ & 5.7 & 19.0 \\
\hline \multicolumn{5}{|c|}{$1-2$ nd instar } \\
\hline $\mathrm{NaOCl}$ & & $25.0 \mathrm{a}$ & 10.8 & 42.4 \\
\hline Thiram & & $25.4 \mathrm{a}$ & 13.8 & 54.3 \\
\hline \multirow{2}{*}{\multicolumn{5}{|c|}{$3-5$ instar }} \\
\hline & & & & \\
\hline $\mathrm{NaOCl}$ & & $14.2 \mathrm{a}$ & 1.8 & 12.6 \\
\hline Thiram & & $11.6 \mathrm{a}$ & 1.7 & 14.6 \\
\hline \multirow{2}{*}{\multicolumn{5}{|c|}{ Adult }} \\
\hline & & & & \\
\hline $\mathrm{NaOCl}$ & & $12.4 \mathrm{~b}$ & 0.0 & 0.0 \\
\hline Thiram & & $9.4 \mathrm{a}$ & 0.0 & 0.0 \\
\hline Untreated & & $10.1 \mathrm{a}$ & 0.0 & 0.0 \\
\hline
\end{tabular}

120 replications.

2 Means in an age interval not followed by the same letter are significantly different ( $P<0.05$ ) (Duncan's multiple range test). 
come limited in quantity, but over time, the nymphs may have been able to accumulate enough of this factor(s) to enable it eventually to mature. We have also found extended development times of nymphs in other colonies under study, especially where corn sections were not changed as frequently or environmental conditions were not controlled as strictly as in these tests. However, regardless of this extended time, the hairy chinch bug can be successfully reared in the laboratory using the above described procedure.

Female longevity and oviposition.-There were no significant differences between laboratory and field collected adults in longevity or oviposition although field adults laid more eggs (170 vs 118) and lived longer (102 vs 73 days). We could not find reports of similar data on the hairy chinch bug in the literature. However, Janes (1935) and Dahms (1947) reported on the oviposition and longevity of $B$. leucopterus reared on wheat and sorghum, respectively. Janes (1935) found that field collected adults laid an avg. of 532 eggs and lived for an avg. period of 94 days at $24.5^{\circ} \mathrm{C}$ on young wheat plants. Dahms (1947) reported $B$. leucopterus feeding on sorghum seedlings grown in balanced nutrient solutions produced an avg. of 189 eggs and lived an avg. of 45.9 days. The much greater oviposition rate and greater gevity reported by Janes (1935) than Dahms (1947) may result from the fact that Janes (1935) changed material daily, or it may be due to differences in host plants (wheat vs sorghum) on the insects. Similarly, the lower rate we obtained may be due to host plant, the use of excised material, or possibly inherent differences between Blissus species.

Preoviposition. - A preoviposition period of $10.8 \pm 4.4$ days was recorded for 1 st generation laboratory-reared adults. Of the 68 females ovipositing, 51 laid eggs within 30 days. Of these ca. $80 \%$ oviposited between 5-14 days. Janes (1935) reported field populations of $B$. leucopterus oviposited at 9 days with a range of 515 days at $24^{\circ} \mathrm{C}$.

We concluded that hairy chinch bugs reared on com sections by the procedures described were similar enough in development rates, reproductive capacity and longevity to field collected insects to warrant use of this method for rearing colonies. The method proved to be superior to rearing insects on rooted plants, because of the ease of retrieval and access of any given stage for test purposes. This satisfactory laboratory rearing method enables year-around availability of the hairy chinch bug, with reduced dependence on natural populations as a source of test insects.

\section{Acknowledgment}

This research was sponsored under USDA, SEA, AR Cooperative Agreement No. 12-14-1001-617 between the Field Crops Laboratory and University of Maryland. Part of a dissertation submitted in partial fulfillment of the Ph.D. degree, Dept. of Entomology, University of MD.

\section{REFERENCES CITED}

Chambliss, C. E. 1895. The history of the chinch bug in Tennessee. Tenn. Agric. Exp. Stn. Bull. 4: 41-55.

Dahms, R. G. 1947. Oviposition and longevity of chinch bugs on seedlings growing in nutrient solutions. J. Econ. Entomol. 40: 841-845

Janes, M. J. 1935. Oviposition studies on the chinch bug, Blissus leucopterus Say. Ann. Entomol. Soc. Am. 25: $109-1020$.

Leonard, D. E. 1966. Biosystematics of the "leucopterus complex" of the genus Blissus. Conn. Agric. Exp. Stn. Bull. 677: 47 pp.

Luginbill, P. 1922. Bionomics of the chinch bug. USDA Bur. Entomol. Bull. 1016: 14 pp.

Parker, F. W. and W. M. Randolph. 1972. Mass rearing the chinch bug in the laboratory. J. Econ. Entomol. 65: 8945.

Snelling, R. O., R. H. Painter, J. H. Parker, and w. M. Osborne. 1937. Resistance of sorghum to chinch bug. USDA Tech. Bull. 585: 56 pp.

Streu, H. T. and C. Cruz. 1972. Control of the hairy chinch bug in turfgrass in the Northeast with Dursban insecticide. Down to Earth 28: 1-4.

Sweet, M. H. 1964. The biology' and ecology of the Rhyparochrominae of New England (Heteroptera: Lygaeidae). Part I. Entomol. Am. 43 (N.S.): 124 pp. 